\title{
Effects of nutrition on the fertility of lactating dairy cattle
}

\author{
R. M. Rodney, ${ }^{\star} \dagger$ P. Celi, $₫ \S$ W. Scott, ${ }^{*}$ K. Breinhild, ${ }^{*}$ J. E. P. Santos,\# and I. J. Lean ${ }^{*}{ }^{1}$ \\ ${ }^{*}$ Scibus, Camden, New South Wales, Australia 2570 \\ †Faculty of Veterinary Science, School of Life and Environmental Sciences, The University of Sydney, Camden, New South Wales, Australia 2570 \\ fDSM Nutritional Products, Animal Nutrition and Health, Columbia, MD 21045 \\ $\S$ Faculty of Veterinary and Agricultural Sciences, The University of Melbourne, Parkville, Victoria, Australia 3010 \\ \#Department of Animal Sciences, University of Florida, Gainesville 32611
}

\section{ABSTRACT}

This meta-analysis of 39 experiments containing 118 treatments explored the effects of diet interventions in early lactation on the proportion of dairy cows pregnant to artificial insemination (AI; pregnancy to AI) and on calving to pregnancy interval. It also identified factors that may explain variation in these responses. The objectives were to identify effects of diet on reproduction, rather than differences between specific dietary interventions. The examination of calving to pregnancy interval used the more traditional method of analyzing differences between a treatment and the reference treatment used for comparison within a given experiment. The systematic review identified fewer experiments $(\mathrm{n}=39)$ than had been expected. Four different multivariable models including the random effect of experiment were used to examine the effects of CPM-Dairy (version 3.08) estimated diet and production variables on proportion pregnant to AI. These models examined (1) output of products, (2) balance or duodenal availability of nutrients, (3) intake of nutrients, or (4) percentage of nutrients in the diet. The multivariable models identified positive associations between estimated increased fatty acid intake [incidence rate ratio $(\mathrm{IRR})=1.0003 \pm 0.0001 \mathrm{~g} / \mathrm{d} ; \pm$ standard error], starch intake (IRR $=1.061 \pm 0.029 \mathrm{~kg} / \mathrm{d}$ ), metabolizable energy balance $(\mathrm{IRR}=1.004 \pm 0.002$ $\mathrm{MJ} / \mathrm{d})$, and duodenal C14:0 $(\mathrm{IRR}=1.008 \pm 0.004 \mathrm{~g} / \mathrm{d})$ availability with the proportion of cows pregnant to AI, whereas rapidly fermentable sugar intake $(\mathrm{IRR}=$ $0.813 \pm 0.054 \mathrm{~kg} / \mathrm{d}$ ), percentage of sugar in the diet $(\mathrm{IRR}=0.960 \pm 0.015 \%)$, and milk protein yield (IRR $0.922 \pm 0.022 \mathrm{~g} / 100 \mathrm{~g}$ per day) were associated with a reduced proportion of cows pregnant to AI. There was no multivariable model developed to assess variables

Received October 29, 2017.

Accepted February 15, 2018.

${ }^{1}$ Corresponding author: ianl@scibus.com.au associated with calving to pregnancy interval but, univariably, increased metabolizable energy balance was associated with a shorter calving to pregnancy interval whereas increased milk production was associated with longer time to pregnancy. Increased intake of some AA, particularly threonine and lysine, were associated with a longer calving to pregnancy interval. It is clear nutritional management around calving can influence reproductive success. The importance of dietary fats and increased energy and protein balances in early lactation for improved fertility outcomes is supported and suggests that starch and sugars may have different effects on the proportion of cows that are pregnant to AI. This work also highlighted a need for further focused field studies exploring the roles of specific fatty acids, AA, phosphorus, and carbohydrates on reproduction.

Key words: carbohydrate, fats, fertility, protein

\section{INTRODUCTION}

Poor reproductive performance of lactating dairy cattle is a complex disorder that reflects associations with intensification of production and increased milk production (Butler, 2000; Lucy, 2001; Lean et al., 2008; Berry et al., 2014). However, it is difficult to determine a causal basis for the decrease in fertility, as genetics and environment have changed markedly over the last decades. Although some of the decline in fertility observed in the past is associated with genetic selection for greater milk production, the heritability of reproductive disorders is weak (Pryce et al., 1997; Berry et al., 2014). This suggests that much of the decline previously observed was associated with changes in nutrition, housing, and herd management and interactions of these environmental changes with genetics.

Nutritional influences on fertility have been examined and frequently reviewed (Butler, 2000; Bisinotto et al., 2012; Friggens et al., 2013), but difficulties and inconsistencies in study design occur. Studies must have large numbers of experimental units to identify biologically and economically important differences 
in proportion of cows pregnant (Lean et al., 2016). Nutritional influences during the transition period ( \pm 4 wk of calving) may be of particular importance (Overton and Waldron, 2004), but it is clear that the effect of diet on fertility during this period is complex and multifactorial. Further, confounding is present in nutritional experiments, as the addition of one nutrient inherently alters concentrations of other nutrients in the diet (Lean et al., 2012). Nutrients may also interact to alter availability, uptake, or production of other nutrients and influence energy partitioning and future milk production beyond the period of immediate intervention (Block, 1984; van Saun et al., 1993; Degaris et al., 2008; Lean et al., 2014). Therefore, although experiments examining single nutritional interventions are essential to develop understandings of dietary components on reproductive outcomes, responses can be difficult to evaluate due to the potential for confounding. Meta-analysis using published literature provides the opportunity to combine studies and overcome the confounding caused by changes in single diets. It also allows the use of existing data to address hypotheses that could not be addressed previously, increases study power, and provides measures of the variation, or heterogeneity, of results among a group of experiments (Lean et al., 2009).

The effects of some nutritional interventions on pregnancy and time to pregnancy have been examined using meta-analysis (de Veth et al., 2009; Rabiee et al., 2010; Lean et al., 2012; Rodney et al., 2015). These studies used randomized controlled experiments that evaluated either the addition of fats (de Veth et al., 2009; Rodney et al., 2015), organic trace minerals (Rabiee et al., 2010), or protein (Lean et al., 2012) on reproductive outcomes. Few experiments have been identified that examine the effects of carbohydrate fractions on fertility, which has previously limited the ability to examine these specific dietary components using meta-analysis. Consequently, the effects of carbohydrate fractions were of interest in the current study.

The concept underpinning the current study is that reproductive failure in a group of cows is, in part, a metabolic disorder reflecting the inability of diets to supply adequate intakes, concentrations, or ratios of nutrients that are required for optimal reproductive performance. Our objective was to use carefully described dietary information from the available literature to explore the effects of the diet during the transition period on measures of pregnancy and calving to pregnancy interval as well as identifying factors that may explain variation in these responses. We hypothesized that dietary formulation and intake of nutrients during the transition period affect the probability of pregnancy to $\mathrm{AI}$ and interval from calving to pregnancy in dairy cows. Previous meta-analyses examining the effects of nutritional interventions during transition on reproduction identified surprisingly few papers that were suitable for inclusion (Lean et al., 2012; Rodney et al., 2015). The current study of the proportion pregnant to AI differs from previously conducted meta-analyses in that the proportion pregnant for each treatment represents a single observation, whereas previous studies have examined the difference in proportion pregnant between a reference and treatment group. The former approach allows a focus on the effects of overall diet on reproduction rather than differences between specific interventions. As such, all nutrients and potential interactions among these could be examined, irrespective of whether they were the intended intervention of a particular diet. The examination of calving to pregnancy interval used the more traditional method of using the difference between treatment and a reference group for each variable in analyses.

\section{MATERIALS AND METHODS}

\section{Literature Search}

A systematic review across 3 databases (PubMed, Web of Science CABI, and Google Scholar) and references in papers was used to identify experiments exploring nutritional interventions during transition and fertility outcomes that were published in English between 1970 and 2015 in a peer-reviewed journal, conference proceedings, or as an accepted thesis. Combinations of the following search terms were used: cow, cattle, dairy, fertility, pregnancy, conception, reproduction, bvitamin, $\beta$-carotene, biotin, calcium, CLA, cobalt, conjugated linoleic acid, copper, cottonseed, energy, fat, fiber/fibre, manganese, magnesium, minerals, molybdenum, omega-3, organic minerals, phosphorous, protein, selenium, soy, soybean meal, vitamin $\mathrm{A}$, vitamin $\mathrm{ADE}$, vitamin $\mathrm{D}$, vitamin $\mathrm{E}$, Zinpro, and zinc. The intent of searching "Zinpro" was to identify studies conducted on commercial mineral mixes. Results were ordered by relevance according to the database and articles were assessed until we found 500 chronological papers that, from the title, appeared unrelated to the topic and unworthy of further review.

\section{Inclusion and Exclusion Criteria}

For clarity of reporting these results, individual nutritional treatments will be referred to as treatments and manuscripts or published papers that report one or more treatments will be referred to as experiments. For calving to pregnancy interval, the difference between 2 treatments is used and is referred to as a comparison. 
Treatments were suitable for inclusion if they were from randomized controlled experiments using Bos taurus dairy cows in their first or later lactation during the dry or lactating period (i.e., nulliparous nonlactating heifers were excluded). Experiments had to evaluate the effect of individually feeding cows during the transition period (up to 4 wk pre- or postpartum) and describe the diet in enough detail that it could be evaluated using CPM-Dairy (version 3.08; Cornell-Penn-Miner, https://cahpwww.vet.upenn.edu/archives/9-Purchase -CPM-3.0.8.1.html). Experiments reporting both preand postcalving interventions were identified in the systematic review; however, the low number of experiments reporting precalving diets meant analysis was confined to postcalving treatments only. The number of cows in each treatment and, for continuous variables, measures of variance or $P$-values that allowed an estimate of standard deviation to be derived must have been reported. Fertility measures must have been reported as (1) proportion of cows pregnant to first AI, second AI, or within $28 \mathrm{~d}$ of breeding season, before 126 DIM, or within the lactation (labeled throughout the manuscript as proportion pregnant to $\mathrm{AI}$ ); or (2) calving to pregnancy interval or days open (labeled throughout the manuscript as calving to pregnancy interval). These fertility measures are detailed for each experiment in Table 1. The numerator for the proportion of cows pregnant was the cows pregnant and the denominator was the number of cows in the group with experiments reporting pregnancy to a single service (Table 1). Appropriate experimental design including details of randomization, suitable analysis, and elimination of bias or confounding was also evaluated.

\section{Data and Diet Extraction}

Data were extracted from each published paper, including authors, year of publication, reference (including journal) of the publication, title of the publication, parity of cows (first or multiple lactations), and number of cows in treatment and reference groups. As stated, reproductive variables examined were defined as proportion of cows pregnant to $\mathrm{AI}$ and calving to pregnancy intervals for each treatment. A summary of experiments and treatments included in the analysis is provided in Table 1.

To extract and model dietary information, data from accepted experiments were entered into CPM-Dairy (version 3.08) following the standard operating procedure described in Rabiee et al. (2012). Ration composition and intake in the experiments were entered using ingredients selected from the standard CPM-Dairy feed bank and calibrated to the specifications described in the experiment. Preference was given to revising nutri- ent compositions of forages. No nutrient content revisions beyond expected typical biological variation were identified. Once calibrated for the reference treatments, no further corrections were made to the analyses of individual components during modeling of the treatment diet. It was assumed that the same forages were used in all treatments of a given experiment, and any tested difference in the comparison of diet analyses within an experiment would likely reflect the distribution of errors around feed sampling and analysis. These data were combined with information on the cattle, including breed, parity, BCS, and BW, and production, housing, and environment from the paper to predict diet composition and outcomes. Body weight was estimated for 5 studies and BCS for 9 studies. Individual dietary components and production factors were extracted. Throughout the current paper, the international system of units was used; a full list of variables assessed and units used are presented in Table 2.

\section{Statistical Analysis}

All statistical analyses were conducted using Stata (Intercooled Stata v.13 and v.14, Stata Corp., College Station, TX). Following initial exploration of the data, a Poisson regression indicated that the data were overdispersed and use of a negative binomial model for data analysis was indicated. Negative binomial metaregression analyses (NBREG) were used to explore the effect of each predictive variable (e.g., dietary component or output) extracted on proportion of cows pregnant, and the contribution of each observation was weighted by the number of cows on the treatment. The unit of interest was each individual treatment within study. Variance in the proportion of pregnant cows was examined by generalized linear latent and mixed models (GLLAMM; Skrondal and Rabe-Hesketh, 2004; Grilli and Rampichini, 2006). The variance attributable to treatment was small ( $<3 \%$ of total variance) and the variance attributable to experiment was approximately $30 \%$ of the total variance. Consequently, the random effect of experiment, but not treatment, was included in the statistical models developed. Variables with univariable $P<0.20$ in the negative binomial analysis were assessed in population averaging, multivariable models (XTNBREG) with backward elimination, in which the random effect of experiment was accounted for. The multivariable models were developed to understand responses further and control for confounding among variables.

The population averaging model is an equal withinpanel (experiment) robust correlation model for the dispersion parameter $\left(\delta_{i}\right)$. As described by Hausman et al. (1984) for a random-effects overdispersion model, 


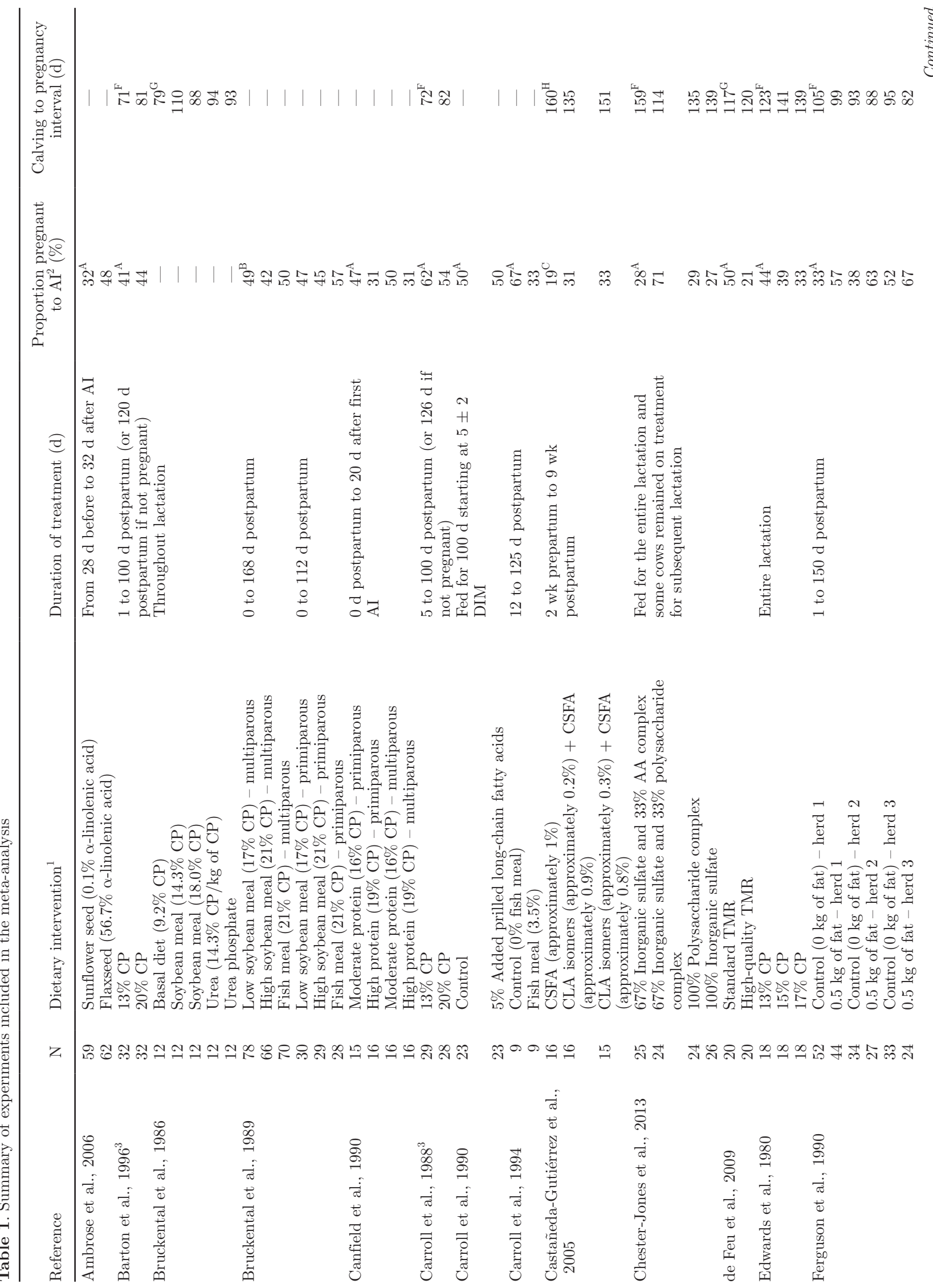


NUTRITION AND FERTILITY: A META-ANALYSIS

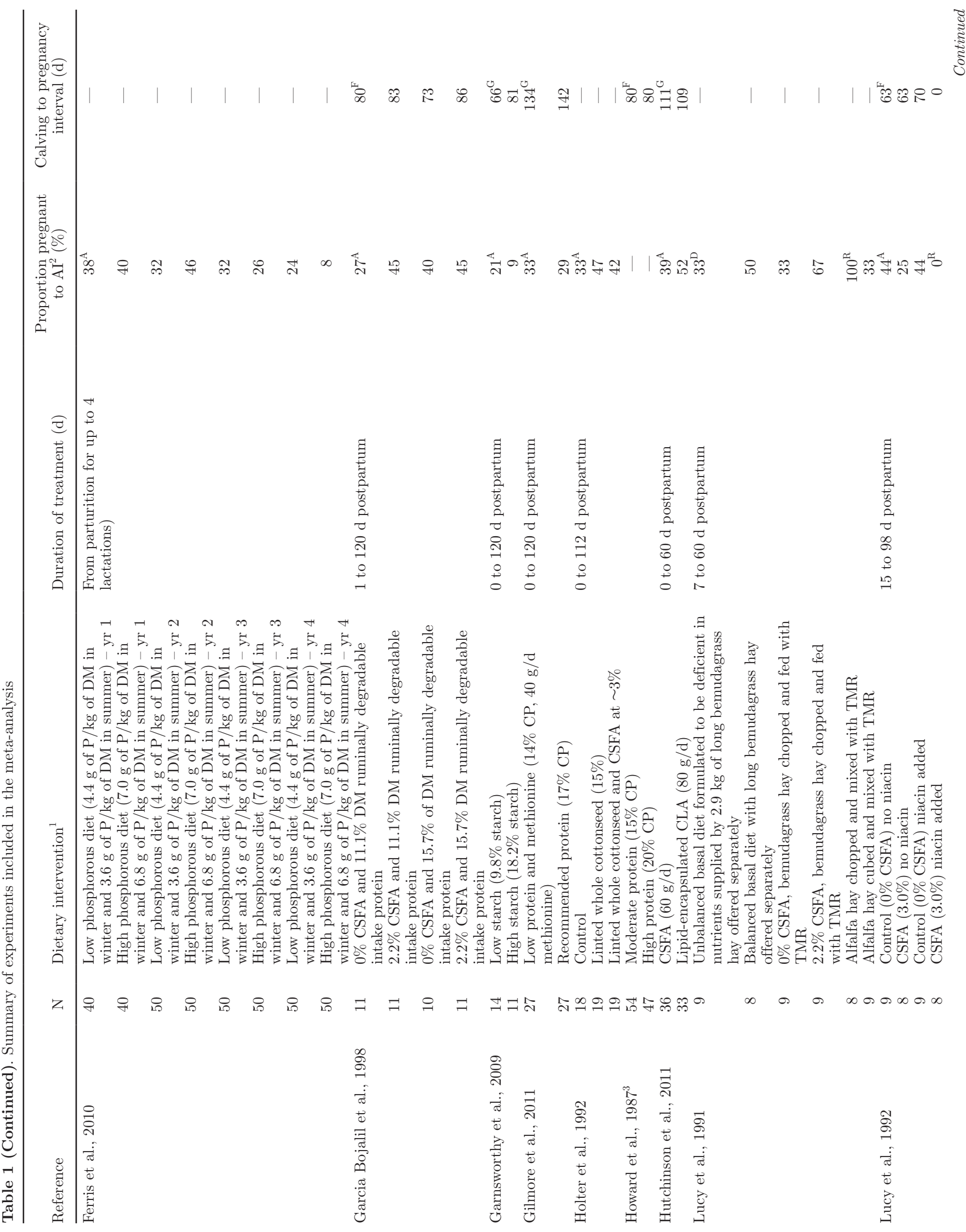




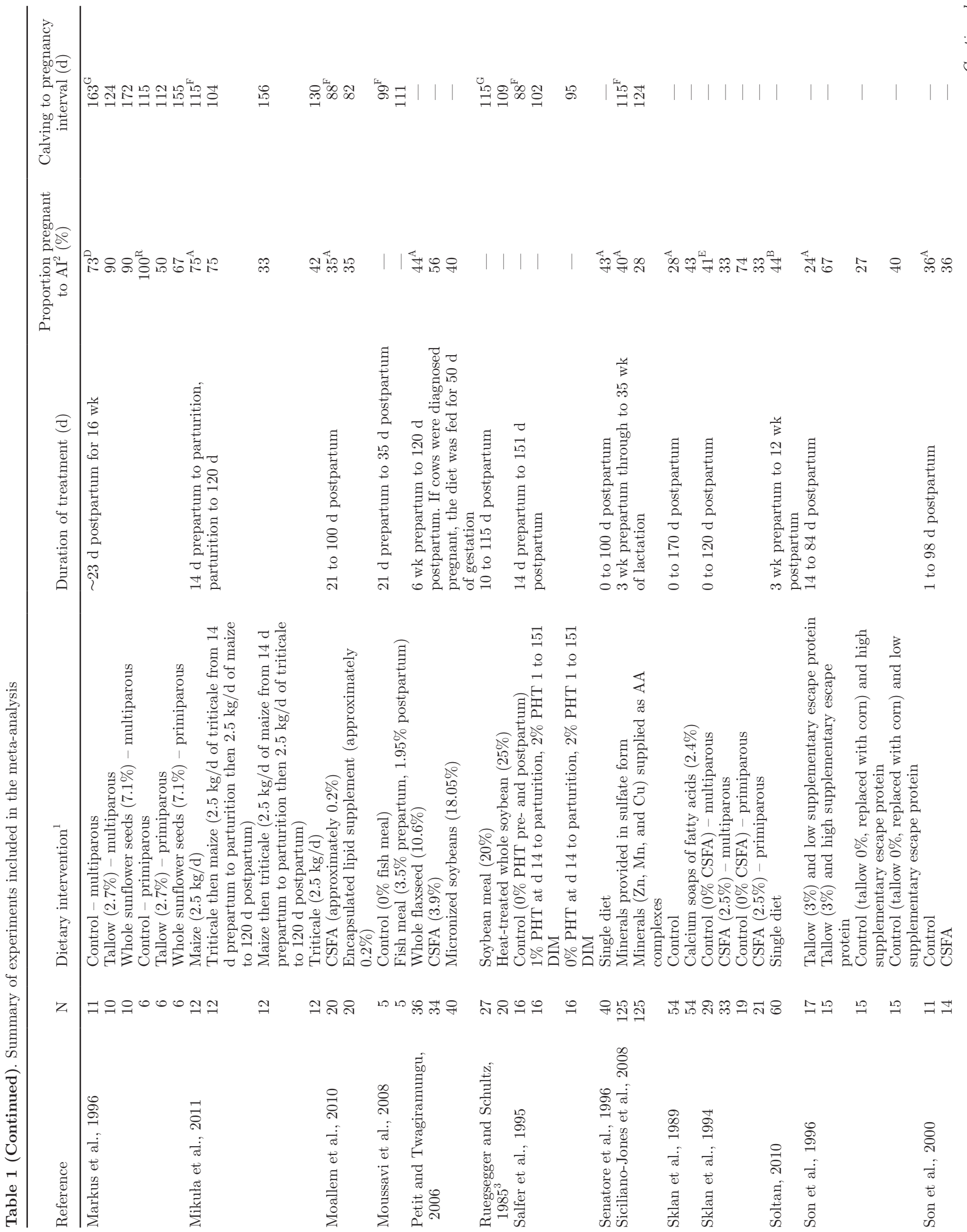


$\delta_{i}$ is allowed to vary randomly across groups; namely, it is assumed that that $1 /\left(1+\delta_{i}\right) \sim \operatorname{Beta}(r, s)$, where $r, s$ are parameters for $\delta_{i}$. The joint probability of the counts for the ith group is

$$
\begin{aligned}
& \operatorname{Pr}\left(Y_{i 1}=y_{i 1}, \ldots, Y_{i n_{i}}=y_{i n_{i}} \mid X_{i}\right)= \\
& \int_{0}^{\infty} \prod_{t=1}^{n_{i}} \operatorname{Pr}\left(Y_{i t}=y_{i t} \mid x_{i t}, \delta_{i}\right) f\left(\delta_{i}\right) \mathrm{d} \delta_{i}= \\
& \frac{\Gamma(r+s) \Gamma\left(r+\sum_{t=1}^{n_{i}} \lambda_{i t}\right) \Gamma\left(s+\sum_{t=1}^{n_{i}} y_{i t}\right)}{\Gamma(r) \Gamma(s) \Gamma\left(r+s+\sum_{t=1}^{n_{i}} \lambda_{i t}+\sum_{t=1}^{n_{i}} y_{i t}\right)} \prod_{t=1}^{n_{i}} \frac{\Gamma\left(\lambda_{i t}+y_{i t}\right)}{\Gamma\left(\lambda_{i t}\right) \Gamma\left(y_{i t}+1\right)},
\end{aligned}
$$

for $X_{i}=\left(x_{i} 1, \ldots, x_{i n i}\right)$ and where $f$ is the probability density function for $\delta_{i}$. The $Y_{i t}$ is the count of the th observation in the $i$ th group, $n$ is the observed event count for unit $i$ during the time period $t, \lambda_{i t}$ is the Poisson parameter, and $\Gamma$ is the gamma function. The resulting log-likelihood is

$$
\ln L=\sum_{i=1}^{n} \omega_{i}\left\{\begin{array}{l}
\ln \Gamma(r+s)+\ln \Gamma\left(r+\sum_{k=1}^{n_{i}} \lambda_{i k}\right)+\ln \Gamma\left(s+\sum_{k=1}^{n_{i}} y_{i k}\right) \\
-\ln \Gamma(r)-\ln \Gamma(s)-\ln \Gamma\left(r+s+\sum_{k=1}^{n_{i}} \lambda_{i k}+\sum_{k=1}^{n_{i}} y_{i k}\right) \\
+\sum_{t=1}^{n_{i}}\left[\ln \Gamma\left(\lambda_{i t}+y_{i t}\right)-\ln \Gamma\left(\lambda_{i t}\right)-\ln \Gamma\left(y_{i t}+1\right)\right]
\end{array}\right\},
$$

where $\lambda_{i t}=\exp \left(x_{i t} \beta+\right.$ offset $\left._{i t}\right)$ for estimates $k=1 \ldots n_{i}$ and $\omega_{i}$ is the weight for the $i$ th group. Four models were examined: (1) output of products, (2) balance or duodenal availability of nutrients, (3) intake of nutrients, or (4) percentage of nutrients in the diet. Statistical significance was accepted if $P<0.05$. Diets $(\mathrm{n}=3)$ that resulted in 0 or $100 \%$ pregnancy (Lucy et al., 1991, 1992; Markus et al., 1996) created instability in the models and were removed from analyses. Collinearity among variables was explored for all models developed using the Collin function in Stata that provides the variance inflation index and condition number. Collinearity, as indicated by a condition index $>50$ (data not provided) for starting models in the multivariable analysis for CPM-estimated metabolizable AA and duodenal fatty acids, was present and model coefficients were unstable during backward stepping procedures. If more than one strongly collinear variable qualified for entry into a model, one variable was chosen based on biological significance, rather than solely on $P$-values. Plausible quadratic relationships for variables were evaluated. Because of collinearity observed among CPM-predicted fatty acid intakes that had individual positive associations with the proportion pregnant, 
Table 2. Summary of mean, SD, minimum, and maximum values observed in the experiments and estimated by $\mathrm{CPM}^{1}$; all estimates are based on 118 observations, except for BW $(\mathrm{n}=113)$ and BCS $(\mathrm{n}=109)$

\begin{tabular}{|c|c|c|c|c|}
\hline Variable & Mean & $\mathrm{SD}$ & Minimum & Maximum \\
\hline BW (kg) & 588.5 & 38.6 & 488 & 663 \\
\hline $\mathrm{BCS}(1-5)$ & 2.8 & 0.3 & 2.3 & 3.7 \\
\hline Milk production $(\mathrm{kg} / \mathrm{d})$ & 33.4 & 6.1 & 19.1 & 52.9 \\
\hline Milk protein (\%) & 3.1 & 0.2 & 2.7 & 3.7 \\
\hline Milk protein yield $(\mathrm{kg} / \mathrm{d})$ & 1.0 & 0.2 & 0.6 & 1.6 \\
\hline Milk fat (\%) & 3.5 & 0.4 & 2.3 & 4.3 \\
\hline Milk fat yield $(\mathrm{kg} / \mathrm{d})$ & 1.2 & 0.2 & 0.6 & 1.7 \\
\hline DMI $(\mathrm{kg} / \mathrm{d})$ & 20.6 & 2.7 & 10.2 & 25.1 \\
\hline ME balance $(\mathrm{MJ} / \mathrm{d})$ & 7.1 & 26.0 & -58.5 & 84 \\
\hline MP balance $(\mathrm{g} / \mathrm{d})$ & -102.9 & 291.9 & -799 & 712.3 \\
\hline $\mathrm{CP}(\%)$ & 18.0 & 2.4 & 10.8 & 25.6 \\
\hline CP eaten $(\mathrm{kg} / \mathrm{d})$ & 3.7 & 0.7 & 1.7 & 6.0 \\
\hline RUP (\% CP) & 36.2 & 5.5 & 20.4 & 50.4 \\
\hline RUP eaten $(\mathrm{kg} / \mathrm{d})$ & 1.4 & 0.4 & 0.6 & 2.2 \\
\hline $\mathrm{RDP}(\% \mathrm{CP})$ & 63.8 & 5.5 & 49.6 & 79.6 \\
\hline RDP eaten $(\mathrm{kg} / \mathrm{d})$ & 2.4 & 0.5 & 1.1 & 4.3 \\
\hline Soluble protein (\% CP) & 34.1 & 6.5 & 13.0 & 57.9 \\
\hline Soluble protein eaten $(\mathrm{kg} / \mathrm{d})$ & 1.3 & 0.4 & 0.5 & 3.1 \\
\hline Urea cost $(\mathrm{mJ} / \mathrm{d})$ & 0.8 & 2.0 & 0 & 11.6 \\
\hline Methionine $(\mathrm{g} / \mathrm{d})$ & 45.4 & 6.7 & 24.5 & 58.7 \\
\hline Lysine $(\mathrm{g} / \mathrm{d})$ & 147.3 & 24.0 & 62.5 & 188.9 \\
\hline Arginine $(\mathrm{g} / \mathrm{d})$ & 143.0 & 24.4 & 59.5 & 198 \\
\hline Threonine $(\mathrm{g} / \mathrm{d}$ ) & 108.0 & 16.2 & 49.8 & 136.9 \\
\hline Leucine $(\mathrm{g} / \mathrm{d})$ & 184.0 & 32.5 & 104.5 & 260.4 \\
\hline Isoleucine $(\mathrm{g} / \mathrm{d})$ & 111.8 & 17.2 & 54.9 & 139.9 \\
\hline Valine $(\mathrm{g} / \mathrm{d})$ & 126.6 & 21.2 & 60.2 & 179.6 \\
\hline Histidine $(\mathrm{g} / \mathrm{d})$ & 58.2 & 10.2 & 26.9 & 79.7 \\
\hline Phenylalanine $(\mathrm{g} / \mathrm{d}$ ) & 114.9 & 18.7 & 57.5 & 148.9 \\
\hline Tryptophan (g/d) & 34.5 & 5.9 & 15 & 51.2 \\
\hline Total EAA (g/d) & $1,073.7$ & 167.3 & 515.3 & $1,345.1$ \\
\hline Ether extract $(\%)$ & 4.8 & 1.6 & 1.8 & 8.6 \\
\hline Long-chain fatty acids (\%) & 3.8 & 1.5 & $\begin{array}{l}1.0 \\
1.3\end{array}$ & 7.5 \\
\hline C12:0 intake $(\mathrm{g} / \mathrm{d})$ & 6.5 & 6.3 & 0 & 37.5 \\
\hline $\mathrm{C} 14: 0$ intake $(\mathrm{g} / \mathrm{d})$ & 7.8 & 6.5 & 1.0 & 31.4 \\
\hline C16:0 intake $(\mathrm{g} / \mathrm{d})$ & 164.3 & 98.1 & 36.4 & 482.2 \\
\hline C16:1 intake $(\mathrm{g} / \mathrm{d})$ & 5.1 & 6.6 & 0.8 & 41.9 \\
\hline C18:0 intake $(\mathrm{g} / \mathrm{d})$ & 35.4 & 48.1 & 5.0 & 367.8 \\
\hline C18:1 trans intake $(\mathrm{g} / \mathrm{d})$ & 1.9 & 5.8 & 0 & 40.2 \\
\hline C18:1 cis intake $(\mathrm{g} / \mathrm{d})$ & 160.6 & 93.5 & 9.6 & 494.6 \\
\hline $\mathrm{C} 18: 2$ intake $(\mathrm{g} / \mathrm{d})$ & 322.0 & 164.5 & 92.8 & 876.7 \\
\hline C18:3 intake $(\mathrm{g} / \mathrm{d})$ & 65.2 & 61.5 & 16.1 & 531.2 \\
\hline $\mathrm{C}$ other intake $(\mathrm{g} / \mathrm{d})$ & 17.9 & 10.4 & 6.4 & 64.4 \\
\hline C12:0 duodenal availability $(\mathrm{g} / \mathrm{d})$ & 6.5 & 6.3 & 0 & 37.5 \\
\hline C14:0 duodenal availability $(\mathrm{g} / \mathrm{d})$ & 7.8 & 6.5 & 1.0 & 31.4 \\
\hline C16:0 duodenal availability ( $\mathrm{g} / \mathrm{d}$ ) & 178.4 & 94.1 & 9.8 & 486.5 \\
\hline C16:1 duodenal availability $(\mathrm{g} / \mathrm{d})$ & 4.3 & 0.9 & 2.2 & 8.8 \\
\hline C18:0 duodenal availability $(\mathrm{g} / \mathrm{d})$ & 456.6 & 147.0 & 175.5 & 869.2 \\
\hline C18:1 trans duodenal availability $(\mathrm{g} / \mathrm{d}$ ) & 71.6 & 52.7 & 12.2 & 315.3 \\
\hline C18:1 cis duodenal availability (g/d) & 44.2 & 34.9 & $\begin{array}{r}12.2 \\
5.3\end{array}$ & 206.7 \\
\hline C18:2 duodenal availability $(\mathrm{g} / \mathrm{d})$ & 39.6 & 23.9 & 6.1 & 170.9 \\
\hline C18:3 duodenal availability $(\mathrm{g} / \mathrm{d})$ & 3.9 & 4.0 & 0.5 & 27.2 \\
\hline $\mathrm{C}$ other duodenal availability ${ }^{2}(\mathrm{~g} / \mathrm{d})$ & 52.1 & 8.5 & 26.1 & 84.9 \\
\hline Sugar $(\%)$ & 5.1 & 2.3 & 2.1 & 13 \\
\hline Starch (\%) & 26.2 & 7.6 & 8.9 & 47.9 \\
\hline NDF (\%) & 31.9 & 4.7 & 14.4 & 46.1 \\
\hline Physically effective NDF (\%) & 23.2 & 3.9 & $\begin{array}{r}1+.7 \\
5.7\end{array}$ & 31.8 \\
\hline NFC $(\%)$ & 40.8 & 5.6 & 27.8 & 56.5 \\
\hline Fermentable carbohydrate total intake $(\mathrm{kg} / \mathrm{d})$ & 8.7 & 1.2 & 4.8 & 11.2 \\
\hline NDF intake $(\mathrm{kg} / \mathrm{d})$ & 2.1 & 0.5 & 0.2 & 3.5 \\
\hline Starch intake $(\mathrm{kg} / \mathrm{d})$ & 4.3 & 1.3 & 1.5 & 8.5 \\
\hline Soluble fiber intake $(\mathrm{kg} / \mathrm{d})$ & 1.2 & 0.5 & 0.3 & 2.5 \\
\hline Sugar intake $(\mathrm{kg} / \mathrm{d})$ & 1.0 & 0.5 & 0.2 & 2.6 \\
\hline Calcium (\%) & 0.9 & 0.3 & 0.3 & 1.5 \\
\hline Phosphorous (\%) & 0.5 & 0.1 & 0.3 & 1.0 \\
\hline Magnesium (\%) & 0.3 & 0.1 & 0.2 & 0.5 \\
\hline
\end{tabular}

${ }^{1}$ CPM-Dairy (version 3.08; Cornell-Penn-Miner, https://cahpwww.vet.upenn.edu/archives/9-Purchase-CPM3.0.8.1.html).

${ }^{2}$ The $\mathrm{C}$ other are fatty acids other than those listed in Table 2 and with more than 12 carbon atoms. 
these were combined (for those individual fatty acids that had $P<0.20$ ) into positive fatty acids intake (including C14:0, C16:0, C16:1, C18:0, C18:1 trans, C18:1 cis, and other fatty acids intake) and positive fatty acids duodenal availability (including C14:0, C16:0, C16:1, C18:0, C18:1 cis, and other fatty acids duodenal; Table 3). These variables were tested in intake and balance or duodenal availability multivariable models, respectively. Similarly, CPM-predicted metabolizable AA were combined and assessed as a single variable as these were also collinear. Model fit during development of the final model was evaluated using the Wald statistic. No final models had a condition index $>10$ and mean variance inflation factors were $<4$ (data not shown).

Dietary or production variables were used as predictors to explore their associations with calving to pregnancy interval. For those analyses, the difference in interval to pregnancy between a given treatment and the reference treatment within an experiment was the response of interest. Random effects standardized mean difference (SMD), also called effect size (ES) meta-analysis, was used following the method of DerSimonian and Laird (1986) as outlined by Rodney et al. (2015). If the experiment reported separate estimates of the measure of variance [standard error (SE) or standard deviation (SD)] for each treatment, these were recorded as such. Many experiments reported a common SE or SD, and these estimates were used for the multiple treatments. In experiments in which SE was reported, an SD was derived before analysis. Some experiments reported only exact $P$-values and these were used to estimate SD, or, in experiments in which nonsignificance was indicated without an exact $P$-value, $P=0.50$ was used to determine the related SD. To explore sources of heterogeneity of response arising from diet, for each dietary variable the differences between a treatment and the reference treatment within an experiment were calculated and a random effects meta-regression analysis (METAREG; Higgins and Thompson, 2002) was used to screen individual variables. For fat, starch, or energy and mineral interventions, the reference treatment was defined as the diet containing less of the ingredient of interest, or the most commonly used variety of the ingredient based on the a priori hypothesis that increasing fat, starch, or energy or mineral intake would reduce calving to pregnancy interval. Alternatively, increasing the amount of $\mathrm{CP}$ or degradability of protein in the diet has negative effects on fertility (Lean et al., 2012). Consequently, the reference treatment for experiments using protein comparisons was classified as that with the most $\mathrm{CP}$ or RDP inclusion. The individual relative risk was used for each diet as the outcome and the associated SE was used as the measure of variance. A smaller number of comparisons were available for inclusion in our analysis as a result of the fewer diets identified reporting calving to pregnancy interval and the unit of interest being the difference between a treatment and the reference treatment for each comparison. As a result, a multivariable analysis was not conducted for calving to pregnancy interval. A random-effects weighted mean difference (WMD) between the treatment group and reference group is provided for the interval to pregnancy, with the weighting reflecting the inverse of the variance of the treatments included according to the nostandard method in the metan model of Stata to allow an interpretation of treatment effects in familiar units (d) rather than ES. A $P$-value of $<0.05$ was accepted as being significant and $P>0.05$ and $<0.1$ were identified as trends.

\section{RESULTS}

\section{Literature Review and Assessment}

The detailed systematic review identified more than 60,000 results across the 3 databases. If a reason for exclusion could be clearly identified in the title of a paper, the experiment was excluded during the screening phase. Such exclusions included experiments not in English, experiments that used Bos taurus indicus, crossbred cows, or nulliparous nonlactating cows, experiments unrelated to cattle or transition nutrition, abstracts, and reviews. Some experiments contained a single treatment, whereas others reported 2 or more treatments, which were assessed separately. Of the 334 experiments that remained for eligibility, the main reason treatments were excluded from the meta-analysis was that they were not completely randomized experiments with a single treatment assigned per cow (i.e., were reviews, case studies, or Latin square or crossover designs) that assessed nutrition and reproduction during the transition period (65 experiments). Studies that included changes in nutritional intervention during the transition period that could not be adequately quantified from the data reported, including those that used an injectable intervention (160 experiments) and those that used Bos taurus indicus crossbred, beef, or only nulliparous cows (36 experiments), or did not report the reproductive variables specified for inclusion (e.g., ovulation or reproductive hormone concentrations) or unit of interest was the oocyte or conceptus (34 experiments) were excluded. Some of the treatments excluded after assessment for eligibility examined valid interventions, but the experiment contained a lack of detail about the diet or feed intake was not accurately measured (e.g., pasture or group feeding), making the 
Table 3. Univariable effects of production and dietary factors affecting pregnancy to AI and calving to pregnancy interval ${ }^{1}$

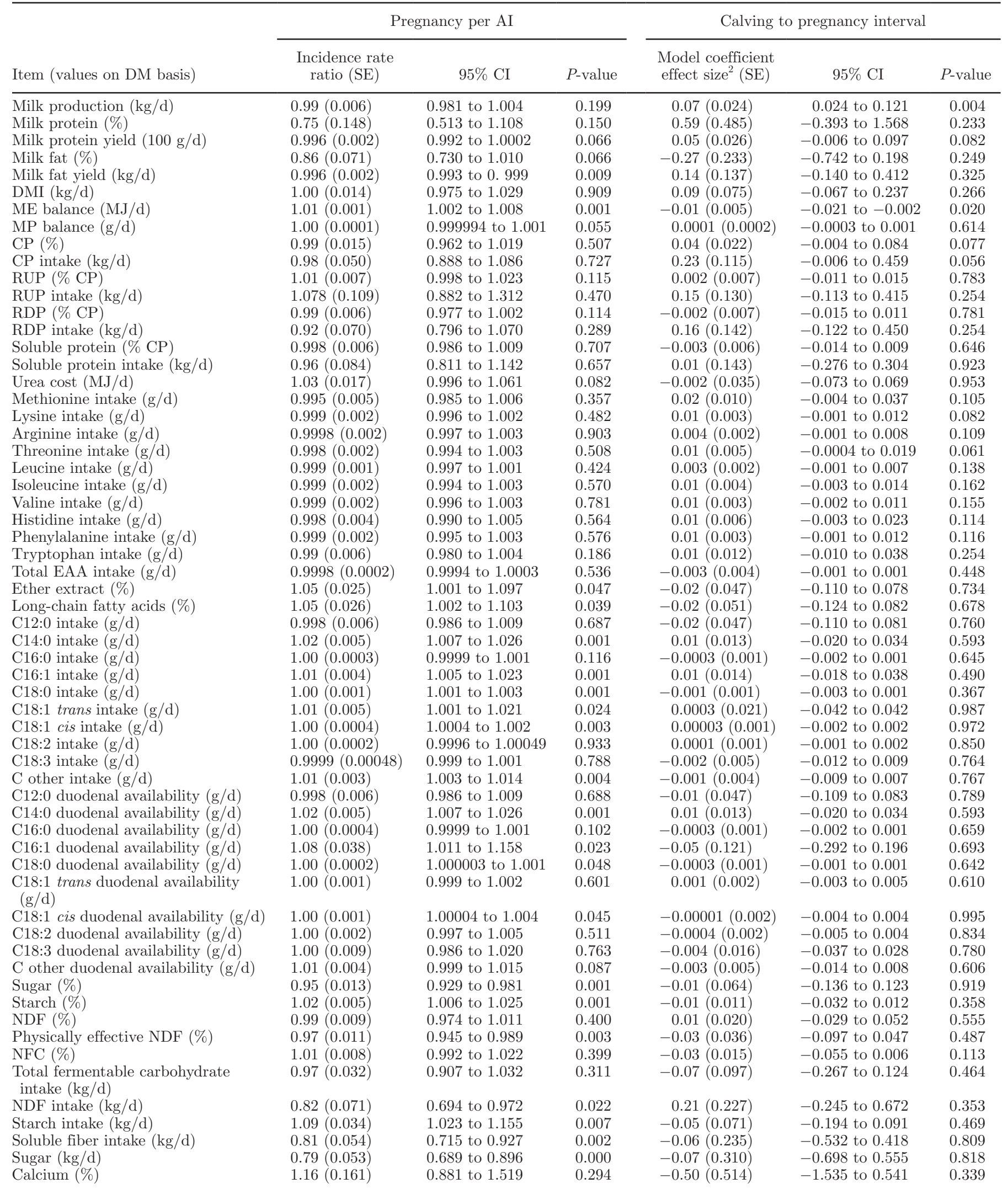


Table 3 (Continued). Univariable effects of production and dietary factors affecting pregnancy to AI and calving to pregnancy interval ${ }^{1}$

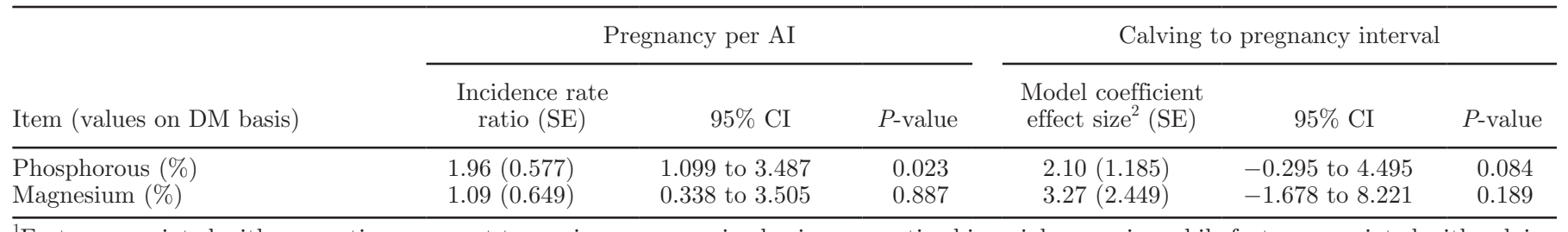

${ }^{1}$ Factors associated with proportion pregnant to service were examined using a negative binomial regression while factors associated with calving to pregnancy interval were assessed using a random effects standardized mean difference (SMD) (effect size) meta-analysis and meta-regression. Differences between a treatment and the reference treatment within experiment for each production and dietary variable were calculated for use in the meta-regression.

${ }^{2}$ Standard deviation $=28.7 \mathrm{~d}$.

diets unsuitable for extraction and inclusion in the current study.

The systematic review identified 39 experiments containing 118 individual treatments that were suitable for inclusion in our analyses of proportion pregnant and calving to pregnancy interval. Of these, 35 experiments with 109 treatments reported proportion of pregnant cows and 23 experiments containing 42 comparisons reported calving to pregnancy interval. The treatments examined a range of dietary interventions with varying inclusion rates and timings of intervention. Few experiments provided details on prepartum diets; hence, the meta-analysis focused on postpartum, early-lactation diets. A further 3 experiments (Colazo et al., 2009; Nowak et al., 2013; Badiei et al., 2014) provided details of precalving diets only and were not included in this analysis. If an experiment reported multiple precalving treatments and a common postcalving diet, the postcalving treatment was used for the multiple groups, but these were included in the analysis as separate treatments. Descriptive statistics of dietary components and production outputs is provided in Table 2 .

\section{Reproduction Outcomes}

The systematic review identified 35 experiments, reporting 109 treatments that provided details of the proportion pregnant. The mean proportion pregnant was $0.44(\mathrm{SD}=0.16)$. Because of the complex nature of, and likely collinearity between, components of the diets, dietary variables and production outputs were classified as reporting the (2) output of nutrient including production, (2) balance or duodenal availability of nutrient, (3) intake amount, or (4) percentage of nutrient in the diet, and these were explored as 4 separate models. Univariable analyses of the associations between each variable and fertility outcomes are detailed in Table 3 and multivariable models including the random effect of experiment for factors affecting the proportion pregnant are described in Table 4.

\section{Proportion Pregnant to Al}

(1) Outputs. In the univariable model (Table 3), milk fat yield $(0.996 \pm 0.002 \mathrm{~kg} / \mathrm{d} ; \pm \mathrm{SE})$ was negatively associated $(P=0.009)$ and milk fat percentage $(0.86$ $\pm 0.071)$ and milk protein yield $(0.996 \pm 0.002 \mathrm{~kg} / \mathrm{d})$ tended to be negatively associated with pregnancy to AI $(P=0.066)$. Although milk production $(\mathrm{kg} / \mathrm{d})$ and milk protein percentage were not associated $(P \geq 0.15)$ with pregnancy to AI (Table 3), they were both included in the multivariable models (Table 4). We noted a tendency for urea cost $(\mathrm{MJ} / \mathrm{d})$ to be positively associated $(1.03 \pm 0.017, P=0.082)$ with pregnancy to AI (Table 3). The multivariable model, accounting for the random effect of experiment, resulted in a negative association of milk protein yield $(0.922 \pm 0.022100 \mathrm{~g} / \mathrm{d}$; $P=0.001)$ with pregnancy to AI (Table 4$)$.

Table 4. Multivariable negative binomial regression models assessing associations between dietary components or production factors and pregnancy to $\mathrm{AI}^{1}$

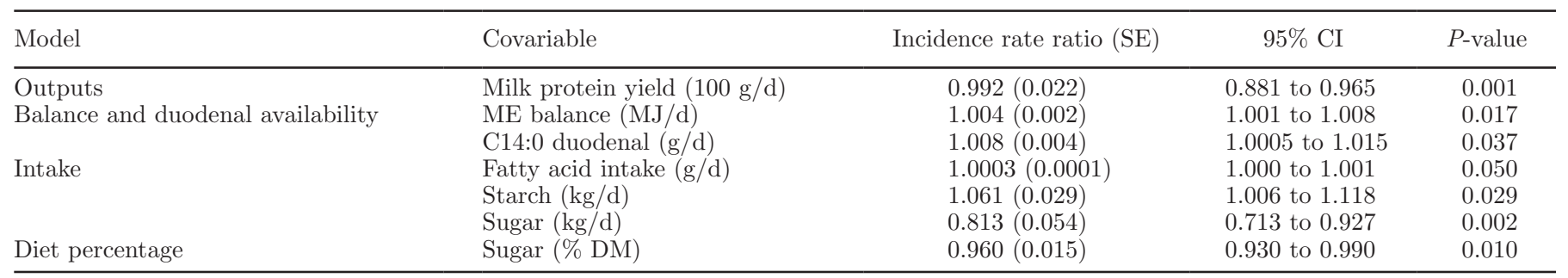

${ }^{1}$ Models accounted for the random effect of experiment. 
(2) Nutrient Balance and Duodenal Availability. The nutrient balance and duodenal availability model was used to analyze associations of CPM estimated ME balance (MJ/d), MP balance $(\mathrm{g} / \mathrm{d})$, and duodenal availabilities of several individual fatty acids (C14:0, C16:0, C16:1, C18:0, C18:1 cis, and other, g/d; Table 3) with pregnancy to AI. The negative association for CPM-estimated metabolizable EAA availabilities $(\mathrm{g} / \mathrm{d})$ with pregnancy to AI were also considered in the development of the multivariable model. When examined in the multivariable model, CPM-estimated ME balance $(1.004 \pm 0.002 \mathrm{MJ} / \mathrm{d})$ and duodenal C14:0 $(1.008 \pm 0.004 \mathrm{~g} / \mathrm{d})$ availability remained in the model, both having positive relationships with pregnancy to AI $(P=0.017$ and 0.037 , respectively, Table 4$)$. The combined positive association between duodenal fatty acid availability (g/d) was also considered for inclusion in this model, but resulted in poorer model fit than the final model that included only C14:0 (g/d).

(3) Intake. The intake model identified positive associations between CPM-estimated individual fatty acid intakes (C14:0, C16:0, C16:1, C18:0, C18:1 trans, C18:1 cis, and other intake, $\mathrm{g} / \mathrm{d})$ or starch intake $(\mathrm{kg} / \mathrm{d})$ with pregnancy to AI (Table 3). The CPM-estimated NDF $(0.82 \pm 0.071 \mathrm{~kg} / \mathrm{d})$, soluble fiber $(0.81 \pm 0.054 \mathrm{~kg} / \mathrm{d})$, and sugar intakes $(0.79 \pm 0.053 \mathrm{~kg} / \mathrm{d})$ were negatively associated with pregnancy to AI $(P=0.022,0.002$, and 0.001 , respectively; Table 3$)$. The multivariable model included combined positive fatty acids intake (g/d), starch intake $(\mathrm{kg} / \mathrm{d})$, and sugar intake $(\mathrm{kg} / \mathrm{d})$. Fatty acid intake $(1.0003 \pm 0.0001 \mathrm{~g} / \mathrm{d})$ and starch intakes $(1.061 \pm 0.029 \mathrm{~kg} / \mathrm{d})$ were positively associated with pregnancy to $\mathrm{AI}(P=0.05$ and 0.029 , respectively), whereas increasing sugar intake $(0.813 \pm 0.54 \mathrm{~kg} / \mathrm{d})$ was associated with decreased pregnancy to AI $(P=$ 0.002, Table 4).

(4) Diet Percentage. In the univariable model, positive associations of the CPM-estimated dietary percentage of ether extract, long-chain fatty acids, starch, and $\mathrm{P}$, and negative associations of the dietary percentage of physically effective NDF and sugar were identified with pregnancy tor AI (Table 3). Sugar percentage alone remained in the multivariable model, having a negative association with pregnancy to AI (0.960 \pm 0.015, $P=0.01$, Table 4).

\section{Calving to Pregnancy Interval}

Twenty-three experiments containing 42 comparisons reported calving to pregnancy interval. The meta-analysis indicated that interventions designed to improve reproductive performance during the transition period tended to numerically reduce the calving to pregnancy interval $(\mathrm{SMD}=-0.05 ; \mathrm{WMD}=0.71 \mathrm{~d}$ less; $95 \% \mathrm{CI}=$ -3.40 to $1.97 \mathrm{~d}$ ), and this result was homogeneous $\left[\mathrm{I}^{2}\right.$ (transformation of the square root of the $\chi^{2}$ heterogeneity statistic divided by its df describing the proportion of total variation in treatment estimates due to heterogeneity) $=0.0 \%$; Figure 1]. As expected from previous meta-analyses (Lean et al., 2012; Rodney et al., 2015), diets that increased the amount of fat $(\mathrm{WMD}=1.64$ less d; $95 \% \mathrm{CI}=-5.28$ to $2.01 \mathrm{~d}$ ) or decreased the amount or degradability of protein in the diet (WMD $7.41 \mathrm{~d}$ less; $95 \% \mathrm{CI}=-13.18$ to -1.63 ) were associated with a shorter calving to pregnancy interval (Figure 1 ), although this was only a tendency for the diets reporting interventions using fats. Increasing dietary starch or energy density tended to increase calving to pregnancy interval, although only 3 diets examined the latter intervention and the confidence interval was large ( $95 \% \mathrm{CI}=-0.14$ to 0.70 ; Figure 1$)$. We noted mixed associations with mineral-based interventions increasing the calving to pregnancy interval $(\mathrm{WMD}=6.77 \mathrm{~d}$ increased; $95 \% \mathrm{CI}=0.82$ to 12.54 ), reflecting varying responses between and within the same experiment. When examined using meta-regression, an increased CPM-estimated difference in $\mathrm{ME}$ balance $(\mathrm{MJ} / \mathrm{d})$ between the treatment and reference treatments was associated with shorter calving to pregnancy interval $(\mathrm{ES}=-0.01 \pm 0.005$ per MJ difference in ME balance per day; $P=0.02$ ), whereas an increased difference in milk production $(\mathrm{kg} / \mathrm{d})$ was associated with longer calving to pregnancy interval $(\mathrm{ES}=0.07 \pm 0.024$ per $\mathrm{kg}$ difference in milk production; $P=0.004$; Table 3 ). An increase of $10 \mathrm{MJ} / \mathrm{d}$ of difference in ME balance would result in $-0.1 \mathrm{ES}$ or $2.87 \mathrm{~d}$ shorter interval to pregnancy based on the SD of $28.7 \mathrm{~d}$ for pregnancy interval. Increased differences between the treatment and reference treatments in $\mathrm{CP}$ percentage $(\mathrm{ES}=0.04$ \pm 0.022 per percentage difference in $\mathrm{CP}), \mathrm{CP}$ intake $(\mathrm{ES}=0.23 \pm 0.115$ per $\mathrm{kg} / \mathrm{d}$ difference in $\mathrm{CP}$ intake), $\mathrm{P}$ percentage $(\mathrm{ES}=2.10 \pm 1.185$ difference in $\mathrm{P}$ intake), and milk protein yield $(\mathrm{ES}=0.05 \pm 0.026$ per $100 \mathrm{~g} / \mathrm{d}$ difference in milk protein yield) tended to be associated $(P<0.09)$ with longer calving to pregnancy interval (Table 3). Increased CPM-estimated metabolizable AA intake, particularly of lysine $(\mathrm{ES}=0.01 \pm$ $0.003 \mathrm{per} \mathrm{g} / \mathrm{d}$ difference in lysine intake) and threonine $(\mathrm{ES}=0.01 \pm 0.005 \mathrm{per} \mathrm{g} / \mathrm{d}$ difference in threonine intake), tended to be associated with increased calving to pregnancy interval $(P=0.082$ and 0.061 , respectively), as did the difference in $\mathrm{Mg}(\mathrm{ES}=3.27 \pm 2.449$; $P=0.189)$ percentage of the treatment and control diets, whereas the differences in NFC percentage $(\mathrm{ES}=$ $-0.03 \pm 0.015, P=0.113)$ tended to be associated with decreased interval (Table 3). 


\begin{tabular}{|c|c|}
\hline Fat & \\
\hline Ruegsegger and Schultz., 1985 & 3.29 \\
\hline Ferguson et al., 1990 & 5.39 \\
\hline Ferguson et al., 1990 & 3.41 \\
\hline Ferguson et al., 1990 & 3.10 \\
\hline Lucy et al., 1992 & 0.96 \\
\hline Salfer et al., 1995 & 1.79 \\
\hline Salfer et al., 1995 & 1.81 \\
\hline Markus et al., 1996 & 1.15 \\
\hline Markus et al., 1996 & 0.66 \\
\hline Markus et al., 1996 & 0.68 \\
\hline Garcia Bojalil et al., 1998 & 1.23 \\
\hline Garcia Bojalil et al., 1998 & 1.17 \\
\hline Castaneda-Gutierrez et al., 2005 & 1.78 \\
\hline Castaneda-Gutierrez et al., 2005 & 1.75 \\
\hline Moallem et al., 2010 & 2.21 \\
\hline Hutchinson et al., 2011 & 3.85 \\
\hline & \\
\hline Starch or energy & \\
\hline Garnsworthy et al., 2009 & 1.34 \\
\hline deFeu et al., 2009 & 2.27 \\
\hline Mikula et al., 2011 & 1.34 \\
\hline Subtotal (I-squared $=0.0 \%, p=0.593$ ) & 4.95 \\
\hline & \\
\hline Mineral & \\
\hline Lucy et al., 1992 & 0.92 \\
\hline Wu et al., 2000 & 0.91 \\
\hline Wu et al., 2000 & 0.89 \\
\hline Toni et al., 2007 & 1.86 \\
\hline Siciliano-Jones et al., 2008 & 14.16 \\
\hline Chester-Jones et al., 2013 & 2.86 \\
\hline Chester-Jones et al., 2013 & 2.78 \\
\hline Chester-Jones et al., 2013 & 2.83 \\
\hline Subtotal $(1-$ squared $=21.3 \%, p=0.260)$ & 27.22 \\
\hline Edwards et al., 1980 & 1.98 \\
\hline Edwards et al., 1980 & 1.99 \\
\hline Bruckental et al., 1986 & 1.26 \\
\hline Bruckental et al., 1986 & 1.35 \\
\hline Bruckental et al., 1986 & 1.34 \\
\hline Bruckental et al., 1986 & 1.34 \\
\hline Howard et al., 1987 & 5.71 \\
\hline Carroll et al., 1988 & 3.19 \\
\hline Barton et al., 1996 & 3.60 \\
\hline Garcia Bojalil et al., 1998 & 1.18 \\
\hline Garcia Bojall et al., 1998 & 1.25 \\
\hline Westwood et al., 2000 & 4.62 \\
\hline Moussavi et al., 2008 & 0.57 \\
\hline Gilmore et al., 2011 & 3.06 \\
\hline Subtotal $(I-$ squared $=0.0 \%, p=0.868)$ & 32.42 \\
\hline & \\
\hline Overall $(1-$ squared $=0.0 \%, p=0.620$ ) & 100.00 \\
\hline NOTE: Weights are from random effects analysis & \\
\hline
\end{tabular}

Figure 1. Forest plot of individual standardized mean difference (SMD), 95\% CI, and weights for comparisons of calving to pregnancy interval of cows fed different nutritional interventions during the early lactation period (weighted mean differences are provided in results). For fat, starch or energy, and mineral comparisons, the reference treatment was the one with less of the ingredient of interest. For protein-based comparisons, the reference treatment was the one with more CP or RDP. Estimates were made of the SMD using a random effects method (DerSimonian and Laird, 1986). The weights that each comparison contributed are in the right-hand column and are indicated by the size of the box. The larger the box, the greater the contribution of that comparison to the overall estimate. The solid vertical line represents a mean difference of zero or no effect. Points to the left of the line represent a reduction in days to pregnancy, whereas points to the right of the line indicate an increase. The upper and lower limit of the line connected to the square represents the upper and lower $95 \%$ CI for the effect size. The overall pooled effects size and 95\% CI are indicated by the diamonds at the bottom of each fat group. The overall effect was highly homogeneous, as indicated by the $\mathrm{I}^{2}$ of $0.00 \%$ (transformation of the square root of the $\chi^{2}$ heterogeneity statistic divided by its df, describing the proportion of total variation in treatment estimates due to heterogeneity), indicating little error attributable to measurement error. 


\section{DISCUSSION}

This study provides a quantitative evaluation of dietary factors and production outputs that are associated with the probability of pregnancy to service and time to pregnancy from 118 diets contained within 39 experiments. The dietary data were extracted rigorously according to previously described methods (Rabiee et al., 2012) using feed data from the experiments themselves and from the CPM-Dairy (v. 3.08) feedbank and calibrating these according to tested data from the experiments. Notwithstanding the rigor applied to diet extraction, and the choice of the CPM model (as it is the most extensively tested; Bateman et al., 2001; Moate et al., 2004, 2006; Tedeschi et al., 2008), limitations in the estimates of dietary components exist. These include limitations or errors of the model, variations in composition and timing of the diets fed, and feed analysis estimations. It is anticipated that these errors are likely to be nondifferential; that is, neither favoring nor supporting the key hypotheses. Under these conditions, errors in estimation are likely to drive hypotheses toward the null and, therefore, our findings are likely to be robust. Although interventions in the prepartum and early lactation period can have long lasting effects on metabolism and fertility, the proximity of dietary changes, for example of protein, to the time of conception or pregnancy can also be crucial. We focused on nutritional interventions fed during the early postpartum period, but it is worth noting that all but 3 of the diets of Canfield et al. (1990) were fed not just in this early lactation but for at least $30 \mathrm{~d}$ into the breeding period. The choice of statistical models used was determined by the use of count data; that is, the proportion of cows pregnant. The decision was made to use a negative binomial, random effects model based on the clustering of treatments within experiments, and overdispersion of the data (Neuhaus et al., 1991). The term overdispersion reflects an evaluation that the variance estimated is larger than the expected count (Rabe-Hesketh and Skrondal, 2008).

Extensive literature has observed that cows with greater milk production generally have poorer fertility (Spalding et al., 1975; Lean et al., 1989; Butler, 2000; Westwood et al., 2002; Pryce et al., 2004), and that genetic selection for increased production can reduce fertility (Hageman et al., 1991; Buckley et al., 2000; Horan et al., 2005; Pollott and Coffey, 2008). Whereas genetic differences were not examined in this data set, we identified associations between increased milk fat $(\mathrm{kg} / \mathrm{d})$ and protein production $(\mathrm{kg} / \mathrm{d})$ with reductions in the proportion pregnant, actual milk yield $(\mathrm{kg} / \mathrm{d})$, and milk protein yield $(100 \mathrm{~g} / \mathrm{d})$ with longer calving to pregnancy interval (Table 3). Milk protein yield (100 $\mathrm{g} / \mathrm{d}$ ) remained in this final model (Table 4), having a greater significance than in the univariable model. The multivariable model accounted for the random effect of experiment, which was an important factor influencing relationships in proportion pregnant, estimated as contributing approximately $30 \%$ of the variance in this outcome in our study. However, protein yield in very early lactation (first $3 \mathrm{wk}$ of lactation) was positively associated with the proportion of first services that resulted in pregnancy (Rodney et al., 2016), and others identified positive associations between milk protein percentage and improved reproductive performance (Buckley et al., 2003; Madouasse et al., 2010; Morton et al., 2016). These findings, overall, highlight possible differences between experiments conducted at the level of the individual and those at the group level. As milk protein production increases in a group of cows, it may be expected that nutrient intakes will need to be more closely aligned with nutrient losses, whereas the individual within the herd with greater production may have better phenotypic adaptation to the environment allowing greater milk protein yield and percentage.

The availability of nutrients that can be allocated to reproduction is not just determined by immediate diet (i.e., the immediate intake of nutrients as DMI), but also by endogenous body tissue reserves, reflected in labile BW and BCS (Lean and Rabiee, 2006). Hence, DMI before and after calving is a key determinant of exogenous nutrient availability. The irreversible loss of nutrients in milk production and use of nutrients for maintenance and growth diminishes the nutrient pool available for reproduction (Baldwin et al., 1987; Friggens et al., 2013). The difference between dietary intake and expenditure determines the nutrient balance, and if a negative balance occurs endogenous reserves are depleted. Many studies have examined the effects of estimated negative energy balance on fertility (Wathes et al., 2007). The length and severity of a negative energy balance at the onset of lactation is largely determined by DMI around calving (Villa-Godoy et al., 1988) and milk yield (Westwood et al., 2002). Estimated energy balance $(\mathrm{MJ} / \mathrm{d})$ was, as anticipated, positively associated with improved proportion pregnant and shorter calving to pregnancy interval (Tables 2 and 3 ). A better energy balance during the first 3 to 4 wk of lactation reduces the interval to first ovulation and increases the probability of pregnancy at the following breeding (Butler and Smith, 1989). Excessively low or high BCS at calving, or extreme losses of BW or BCS in early lactation, are usually associated with impaired reproductive outcomes (Heuer et al., 1999; Pryce et al., 2001; Buckley et al., 2003; López-Gatius et al., 2003). Body weight and BCS change are often used as proxies for energy balance, although they may more correctly 
be interpreted as a reflection of nutrient balances of protein, minerals, specific fatty acids and vitamins, as well as energy.

Although less well explored than ME balance, MP balance is also important for successful reproduction. In our study, improved early-lactation MP balance tended $(P=0.055)$ to increase the proportion pregnant (Table 3). Rodney et al. (2016) found that increased prepartum MP balance slightly decreased the proportion of first services that resulted in pregnancy, highlighting the difference in pre- and postpartum metabolism. Notably, the prepartum MP balance (Rodney et al., 2016) was markedly positive, exceeding $400 \mathrm{~g} / \mathrm{d}$ on average. In contrast, van Saun et al. (1993) found greater milk protein percentage and a trend to fewer services per conception in cows fed more RUP before calving; those cows did not gain weight, suggesting a lesser MP balance than those of Rodney et al. (2016). Increasing $\mathrm{CP}$ intake may increase nutrient loss via increased milk production and have negative effects on fertility (Lean et al., 2012), in association with higher urea nitrogen concentrations in blood (Westwood et al., 1998). Increasing $\mathrm{CP}$ content of the diet does not necessarily increase MP availability, but decreasing the degradability of protein or increasing the fermentability of the diet may be more effective in increasing MP availability.

Alterations in dietary protein may not simply affect MP balance, but also specific AA composition and supply of metabolizable AA. Specific roles for AA in reproductive performance are not well defined. Lysine and methionine have been suggested to be the most co-limiting AA for production, and supplementation of these may increase milk yield, but results are inconsistent (Rogers et al., 1989; Doepel et al., 2004; Ardalan et al., 2010). Supplementation of lactating cows with rumen-protected methionine or lysine has had positive or negligible effects on reproductive outcomes (Rogers et al., 1989; Ardalan et al., 2010). The current study focused on diets in the early lactation period (Table 1), whereas other studies (Rogers et al., 1989; Ardalan et al., 2010) supplemented cows later in lactation (from $4 \mathrm{wk})$. It is notable that the combined EAA (g/d) reduced the proportion of cows pregnant in a univariable model when the effect of experiment was considered (incidence rate ratio $=0.9996 \pm 0.0002 ; P=0.045$ ). Limitations in these data, including a lack of specifically detailed AA profiles of the feeds, may have in part prevented stronger relationships from being observed. Given the importance of protein and the need to increase understandings of roles of specific AA, this should be an area for further investigation.

The tendency for increased protein intake, dietary percentage, or degradability to be associated with reduced calving to pregnancy interval (Figure 1) is consistent with other studies (Folman et al., 1981; Carroll et al., 1994; Butler, 2000; Westwood et al., 2002; Lean et al., 2012). Butler (1998) reviewed the means by which feeding excess protein can be detrimental. The tendency $(P=0.084)$ for CPM-estimated urea cost $(\mathrm{MJ} / \mathrm{d})$ to be positively associated with the proportion of cows pregnant was surprising, and a similarly positive relationship between estimated urea costs and fertility was identified in a meta-analysis examining the effects of feeding fats on fertility (Rodney et al., 2015). This relationship may indicate interactions between dietary components, in particular between CPM-estimated microbial protein production and rumen-available fats, rather than simply the effect of protein content of the diet per se. Optimal levels of proteins and nitrogen in diets containing additional fat need to be reviewed.

Microbial lipolysis and biohydrogenation in the rumen ensure that intake of fatty acids and those available for absorption in the duodenum differ; hence, these issues were explored separately. Fats not only provide an energy source but also are essential precursors for steroid hormones, and the beneficial effects of fat have been observed independently of the provision of energy (Staples et al., 1998). We noted a strong correlation between individual fatty acids and substantial instability identified, as indicated by marked changes in coefficients, in the development of multivariable models when stepwise removal of individual fatty acids was conducted (data not shown). In the current study, intakes of many of the fats (C14:0, C16:1, C18:0, $\mathrm{C} 18: 1$ trans, C18:1 cis, and other, g/d) were univariably associated with an increased proportion of cows pregnant (Table 3). These were combined into a single variable for the multivariable intake analysis to account for the collinearity among the fats. Other fatty acids include those other than those listed in Table 2 that contain more than 12 carbon atoms and include fatty acids with more than 18 carbon atoms, but not C18:3. Consequently, we found no association between C18:3 identified with the proportion of cows pregnant, but fatty acids present in fish oil, docosahexaenoic acid, docosapentaenoic acid, and eicosapentaenoic acid are included in the other fatty acids associated with the proportion of cows pregnant. Strong correlation and collinearity among individual fatty acids was also identified in the balance and duodenal availability model and, whereas a positive association between duodenal myristic acid (C14:0; g/d) and proportion pregnant was identified, this finding may indicate a positive effect of fats on pregnancy, in general, rather than a specific effect of myristic acid intake per se. The positive effects of feeding fats on reproductive outcomes, both proportion pregnant and calving to pregnancy interval (Tables 2 and 3), observed in our study are consistent 
with a previous meta-analysis (Rodney et al., 2015) that found feeding fats improved ( $27 \%$ increase in relative risk) the proportion of cows pregnant and tended to decrease calving to pregnancy interval. In particular, positive effects of CLA on fertility have been identified (de Veth et al., 2009); however, the limited number of diets that fed CLA in this data set and outputs from CPM-Dairy precluded individual investigation, and further examination of this area may be beneficial.

Carbohydrates are important sources of energy for cows, as well as for rumen microorganisms and generally increase the efficiency of protein utilization and microbial protein production (Hoover and Stokes, 1991; Aldrich et al., 1993; Hristov et al., 2005). However, increased concentrations of rapidly fermentable carbohydrates can increase the risk of acidosis (Plaizier et al., 2008). The type of carbohydrate also influences the risk of acidosis, with sugars posing a greater risk than starches (Golder et al., 2012). Consequently, carbohydrates have positive and negative effects on fertility. The positive associations of starch percentage and intake $(\mathrm{kg} / \mathrm{d})$, possibly because of a slower fermentation rate than sugars, and negative associations of soluble fiber and sugar percentage and intake $(\mathrm{kg} / \mathrm{d})$ with proportion pregnant were identified in univariable analyses (Tables 2 and 3). We also found a negative association between increased CPM-estimated physically effective NDF intake $(\mathrm{kg} / \mathrm{d})$ and proportion pregnant in the univariable analysis. The only variable that remained in the multivariable models was the effect of sugar intake $(\mathrm{kg} / \mathrm{d})$, which was negatively associated with the proportion of cows pregnant. Ruminal acidosis may decrease fertility by reducing feed intake, producing a metabolic acidosis leading to detrimental alteration of uterine environment, stimulating inflammation that induces prostaglandin release, and resulting in luteolysis in a process analogous to that of mastitis (Moore et al., 1991; Zebeli et al., 2015).

The positive univariable association between $\mathrm{P}$ percentage and the proportion of cows pregnant is consistent with studies in beef cattle that found improved fertility outcomes with increased dietary $\mathrm{P}$ concentration (Hart and Michell, 1965). However, studies in dairy cattle have not identified an influence of dietary $\mathrm{P}$ on reproduction (Carstairs et al., 1980; Wu and Satter, 2000; Wu et al., 2000), possibly because of the body's ability to provide $\mathrm{P}$ from skeletal stores or because a smaller study power did not allow a rigorous assessment. Ferris et al. (2010) examined cattle over 4 lactations in a study designed to examine long-term depletion of $\mathrm{P}$ stores, and found numerical, yet nonstatistical improvements in several fertility parameters, although this work lacked the study power to examine these robustly.

\section{CONCLUSIONS}

This study highlights several important findings for future research on the effects of transition nutrition on fertility. It confirms that nutritional management of cows during the transition period can have substantial effects on reproductive success, and this finding is consistent with previous meta-analytical studies in this area. The number of well-described diets that were able to be included in the analysis was limited, and less than expected. This lack of large numbers of suitable treatments and the complexity of responses of the cattle to these treatments strongly suggest a crucial need for further focused field experiments exploring the roles of nutrition on reproduction and interactions among dietary components. Overall, this study confirmed earlier findings that excessive protein intake can impair fertility, but that a positive MP balance is consistent with better fertility. However, it may be necessary to increase protein intake when feeding fats, and other work suggests a need to control the MP balance before calving. The role of specific metabolizable AA needs further study. This study confirms the positive effects of feeding fats and highlights a need for detailed studies in this area. We also, critically, identified potential effects of specific carbohydrate fractions, especially sugar $(\mathrm{kg} / \mathrm{d})$, starch $(\mathrm{kg} / \mathrm{d})$, and physically effective NDF $(\mathrm{kg} / \mathrm{d})$ on reproductive outcomes. The importance of increased energy and protein balances in early lactation for improved fertility outcomes was supported.

\section{ACKNOWLEDGMENTS}

This research was supported by Dairy Australia (Melbourne, Victoria Australia) and Scibus (Camden, New South Wales, Australia).

\section{REFERENCES}

Aldrich, J. M., L. Muller, G. Varga, and L. Griel. 1993. Nonstructural carbohydrate and protein effects on rumen fermentation, nutrient flow, and performance of dairy cows. J. Dairy Sci. 76:1091-1105.

Ambrose, D. J., J. P. Kastelic, R. Corbett, P. A. Pitney, H. V. Petit, J. A. Small, and P. Zalkovic. 2006. Lower pregnancy losses in lactating dairy cows fed a diet enriched in alpha-linolenic acid. J. Dairy Sci. 89:3066-3074.

Ardalan, M., K. Rezayazdi, and M. Dehghan-Banadaky. 2010. Effect of rumen-protected choline and methionine on physiological and metabolic disorders and reproductive indices of dairy cows. J. Anim. Physiol. Anim. Nutr. (Berl.) 94:e259-e265.

Badiei, A., A. Aliverdilou, H. Amanlou, M. Beheshti, E. Dirandeh, R. Masoumi, F. Moosakhani, and H. Petit. 2014. Postpartum responses of dairy cows supplemented with n-3 fatty acids for different durations during the peripartal period. J. Dairy Sci. 97:6391-6399.

Baldwin, R. L., J. France, D. E. Beever, M. Gill, and J. H. Thornley. 1987. Metabolism of the lactating cow: III. Properties of mechanistic models suitable for evaluation of energetic relationships and factors involved in the partition of nutrients. J. Dairy Res. 54:133-145. 
Barton, B. A., H. A. Rosario, G. W. Anderson, B. P. Grindle, and D. J. Carroll. 1996. Effects of dietary crude protein, breed, parity, and health status on the fertility of dairy cows. J. Dairy Sci. 79:2225-2236.

Bateman, H. G., J. Clark, R. Patton, C. Peel, and C. Schwab. 2001. Accuracy and precision of computer models to predict passage of crude protein and amino acids to the duodenum of lactating cows. J. Dairy Sci. 84:649-664.

Berry, D. P., E. Wall, and J. Pryce. 2014. Genetics and genomics of reproductive performance in dairy and beef cattle. Animal 8:105121.

Bisinotto, R. S., L. F. Greco, E. S. Ribeiro, N. Martinez, F. S. Lima, C. R. Staples, W. W. Thatcher, and J. E. P. Santos. 2012. Influences of nutrition and metabolism on fertility of dairy cows. Anim. Reprod. 9:260-272.

Block, E. 1984. Manipulating dietary anions and cations for prepartum dairy cows to reduce incidence of milk fever. J. Dairy Sci. 67:2939-2948.

Bruckental, I., D. Drori, M. Kaim, H. Lehrer, and Y. Folman. 1989. Effects of source and level of protein on milk yield and reproductive performance of high-producing primiparous and multiparous dairy cows. Anim. Prod. 48:319-329.

Bruckental, I., H. Tagari, S. Amir, H. Kennit, and S. Zamwell. 1986. The effect on the performance of dairy cattle of plant protein concentration and of urea or urea-phosphate supplementation in the diet. Anim. Prod. 43:73-82.

Buckley, F., P. Dillon, M. Rath, and R. Veerkamp. 2000. The relationship between genetic merit for yield and live weight, condition score, and energy balance of spring calving Holstein Friesian dairy cows on grass based systems of milk production. J. Dairy Sci. 83:1878-1886.

Buckley, F., K. O'sullivan, J. Mee, R. Evans, and P. Dillon. 2003. Relationships among milk yield, body condition, cow weight, and reproduction in spring-calved Holstein-Friesians. J. Dairy Sci. 86:2308-2319.

Butler, W. R. 2000. Nutritional interactions with reproductive performance in dairy cattle. Anim. Reprod. Sci. 60-61:449-457.

Butler, W. R., and R. Smith. 1989. Interrelationships between energy balance and postpartum reproductive function in dairy cattle. J. Dairy Sci. 72:767-783.

Butler, W. R. 1998. Review: effect of protein nutrition on ovarian and uterine physiology in dairy cattle. J. Dairy Sci. 81:2533-2539.

Canfield, R. W., C. Sniffen, and W. Butler. 1990. Effects of excess degradable protein on postpartum reproduction and energy balance in dairy cattle. J. Dairy Sci. 73:2342-2349.

Carroll, D. J., B. A. Barton, G. W. Anderson, and R. D. Smith. 1988. Influence of protein intake and feeding strategy on reproductive performance of dairy cows. J. Dairy Sci. 71:3470-3481.

Carroll, D. J., F. Hossain, and M. Keller. 1994. Effect of supplemental fish meal on the lactation and reproductive performance of dairy cows. J. Dairy Sci. 77:3058-3072.

Carroll, D. J., M. J. Jerred, R. R. Grummer, D. K. Combs, R. A. Pierson, and E. R. Hauser. 1990. Effects of fat supplementation and immature alfalfa to concentrate ratio on plasma progesterone, energy balance, and reproductive traits of dairy cattle. J. Dairy Sci. $73: 2855-2863$.

Carstairs, J. A., D. Morrow, and R. Emery. 1980. Postpartum reproductive function of dairy cows as influenced by energy and phosphorus status. J. Anim. Sci. 51:1122-1130.

Castañeda-Gutiérrez, E., T. Overton, W. Butler, and D. Bauman. 2005. Dietary supplements of two doses of calcium salts of conjugated linoleic acid during the transition period and early lactation. J. Dairy Sci. 88:1078-1089.

Chester-Jones, H., D. Vermeire, W. Brommelsiek, K. Brokken, G. Marx, and J. Linn. 2013. Effect of trace mineral source on reproduction and milk production in Holstein cows. Prof. Anim. Sci. 29:289-297.

Colazo, M. G., A. Hayirli, L. Doepel, and D. J. Ambrose. 2009. Reproductive performance of dairy cows is influenced by prepartum feed restriction and dietary fatty acid source. J. Dairy Sci. 92:2562-2571. de Feu, M., A. Evans, P. Lonergan, and S. T. Butler. 2009. The effect of dry period duration and dietary energy density on milk production, bioenergetic status, and postpartum ovarian function in Holstein-Friesian dairy cows. J. Dairy Sci. 92:6011-6022.

de Veth, M., D. Bauman, W. Koch, G. Mann, A. Pfeiffer, and W. Butler. 2009. Efficacy of conjugated linoleic acid for improving reproduction: A multi-study analysis in early-lactation dairy cows. J. Dairy Sci. 92:2662-2669.

Degaris, P. J., I. Lean, A. Rabiee, and C. Heuer. 2008. Effects of increasing days of exposure to prepartum transition diets on milk production and milk composition in dairy cows. Aust. Vet. J. $86: 341-351$.

DerSimonian, R., and N. Laird. 1986. Meta-analysis in clinical trials. Control. Clin. Trials 7:177-188.

Doepel, L., D. Pacheco, J. Kennelly, M. Hanigan, I. Lopez, and H. Lapierre. 2004. Milk protein synthesis as a function of amino acid supply. J. Dairy Sci. 87:1279-1297.

Edwards, J., E. Bartley, and A. Dayton. 1980. Effects of dietary protein concentration on lactating cows. J. Dairy Sci. 63:243-248.

Ferguson, J. D., D. Sklan, W. Chalupa, and D. Kronfeld. 1990. Effects of hard fats on in vitro and in vivo rumen fermentation, milk production, and reproduction in dairy cows. J. Dairy Sci. 73:2864-2879.

Ferris, C. P., M. McCoy, D. Patterson, and D. Kilpatrick. 2010. Effect of offering dairy cows diets differing in phosphorus concentration over four successive lactations: 2. Health, fertility, bone phosphorus reserves and nutrient utilisation. Animal 4:560-571.

Folman, Y., H. Neumark, M. Kaim, and W. Kaufmann. 1981. Performance, rumen and blood metabolites in high-yielding cows fed varying protein percents and protected soybean. J. Dairy Sci. 64:759-768.

Friggens, N. C., L. Brun-Lafleur, P. Faverdin, D. Sauvant, and O. Martin. 2013. Advances in predicting nutrient partitioning in the dairy cow: recognizing the central role of genotype and its expression through time. Animal 7:89-101.

Garcia-Bojalil, C. M., C. Staples, C. Risco, J. Savio, and W. Thatcher. 1998. Protein degradability and calcium salts of long-chain fatty acids in the diets of lactating dairy cows: Reproductive responses. J. Dairy Sci. 81:1385-1395.

Garnsworthy, P. C., A. Fouladi-Nashta, G. Mann, K. Sinclair, and R. Webb. 2009. Effect of dietary-induced changes in plasma insulin concentrations during the early post partum period on pregnancy rate in dairy cows. Reproduction 137:759-768.

Gilmore, H. S., F. Young, D. Patterson, A. Wylie, R. Law, D. Kilpatrick, C. Elliott, and C. Mayne. 2011. An evaluation of the effect of altering nutrition and nutritional strategies in early lactation on reproductive performance and estrous behavior of high-yielding Holstein-Friesian dairy cows. J. Dairy Sci. 94:3510-3526.

Golder, H. M., P. Celi, A. Rabiee, C. Heuer, E. Bramley, D. Miller, R. King, and I. Lean. 2012. Effects of grain, fructose, and histidine on ruminal $\mathrm{pH}$ and fermentation products during an induced subacute acidosis protocol. J. Dairy Sci. 95:1971-1982.

Grilli, L., and C. Rampichini. 2006. A Review of Random Effects Modelling Using gllamm in Stata. Department of Statistics, University of Florence, Florence, Italy.

Hageman, W. H., G. Shook, and W. Tyler. 1991. Reproductive performance in genetic lines selected for high or average milk yield. J. Dairy Sci. 74:4366-4376.

Hart, B., and G. Michell. 1965. Effect of phosphate supplementation on the fertility of an open range beef cattle herd on the Barkly Tableland. Aust. Vet. J. 41:305-309.

Hausman, J., B. Hall, and Z. Griliches. 1984. Econometric models for count data with an application to the patents-R \& D relationship. Econometrica 52:909-938.

Heuer, C., Y. Schukken, and P. Dobbelaar. 1999. Postpartum body condition score and results from the first test day milk as predictors of disease, fertility, yield, and culling in commercial dairy herds. J. Dairy Sci. 82:295-304.

Higgins, J. P., and S. G. Thompson. 2002. Quantifying heterogeneity in a meta-analysis. Stat. Med. 21:1539-1558. 
Holter, J. B., H. Hayes, W. Urban Jr., and A. Duthie. 1992. Energy balance and lactation response in Holstein cows supplemented with cottonseed with or without calcium soap. J. Dairy Sci. $75: 1480-1494$

Hoover, W. H., and S. Stokes. 1991. Balancing carbohydrates and proteins for optimum rumen microbial yield. J. Dairy Sci. 74:36303644.

Horan, B., J. Mee, P. O'connor, M. Rath, and P. Dillon. 2005. The effect of strain of Holstein-Friesian cow and feeding system on postpartum ovarian function, animal production and conception rate to first service. Theriogenology 63:950-971.

Howard, H. J., E. Aalseth, G. Adams, L. Bush, R. McNew, and L. Dawson. 1987. Influence of dietary protein on reproductive performance of dairy cows. J. Dairy Sci. 70:1563-1571.

Hristov, A. N., J. Ropp, K. Grandeen, S. Abedi, R. Etter, A. Melgar, and A. Foley. 2005. Effect of carbohydrate source on ammonia utilization in lactating dairy cows. J. Anim. Sci. 83:408-421.

Hutchinson, I., M. J. de Veth, C. Stanton, R. J. Dewhurst, P. Lonergan, A. C. Evans, and S. T. Butler. 2011. Effects of lipid-encapsulated conjugated linoleic acid supplementation on milk production, bioenergetic status and indicators of reproductive performance in lactating dairy cows. J. Dairy Res. 78:308-317.

Lean, I. J., J. Galland, and J. Scott. 1989. Relationships between fertility, peak milk yields and lactational persistency in dairy cows. Theriogenology 31:1093-1103.

Lean, I., and A. Rabiee. 2006. Quantitative metabolic and epidemiological approaches to the fertility of the dairy cow. Pages 115-131 in Proceedings of the Dairy Cattle Reproductive Council, Denver, CO.

Lean, I. J., A. Rabiee, T. Duffield, and I. Dohoo. 2009. Invited review: Use of meta-analysis in animal health and reproduction: Methods and applications. J. Dairy Sci. 92:3545-3565.

Lean, I., C. Westwood, and M. Playford. 2008. Livestock disease threats associated with intensification of pastoral dairy farming. N. Z. Vet. J. 56:261-269.

Lean, I. J., P. Celi, H. Raadsma, J. McNamara, and A. R. Rabiee. 2012. Effects of dietary crude protein on fertility: Meta-analysis and meta-regression. Anim. Feed Sci. Technol. 171:31-42.

Lean, I. J., P. J. DeGaris, P. Celi, D. M. McNeill, R. M. Rodney, and D. R. Fraser. 2014. Influencing the future: interactions of skeleton, energy, protein and calcium during late gestation and early lactation. Anim. Prod. Sci. 54:1177-1189.

Lean, I. J., M. C. Lucy, J. P. McNamara, B. J. Bradford, E. Block, J. M. Thomson, J. M. Morton, P. Celi, A. R. Rabiee, and J. E. Santos. 2016. Invited review: Recommendations for reporting intervention studies on reproductive performance in dairy cattle: Improving design, analysis, and interpretation of research on reproduction. J. Dairy Sci. 99:1-17.

López-Gatius, F., J. Yaniz, and D. Madriles-Helm. 2003. Effects of body condition score and score change on the reproductive performance of dairy cows: A meta-analysis. Theriogenology 59:801-812.

Lucy, M. C. 2001. Reproductive loss in high-producing dairy cattle: Where will it end? J. Dairy Sci. 84:1277-1293.

Lucy, M. C., C. Staples, F. Michel, and W. Thatcher. 1991. Energy balance and size and number of ovarian follicles detected by ultrasonography in early postpartum dairy cows. J. Dairy Sci. 74:473482

Lucy, M. C., C. R. Staples, W. W. Thatcher, P. S. Erickson, R. M. Cleale, J. L. Firkins, J. H. Clark, M. R. Murphy, and B. O. Brodie. 1992. Influence of diet composition, dry-matter intake, milk production and energy balance on time of post-partum ovulation and fertility in dairy cows. Anim. Prod. 54:323-331.

Madouasse, A., J. Huxley, W. Browne, A. Bradley, I. Dryden, and M. Green. 2010. Use of individual cow milk recording data at the start of lactation to predict the calving to conception interval. J. Dairy Sci. 93:4677-4690.

Markus, S. B., K. Wittenberg, J. Ingalls, and M. Undi. 1996. Production responses by early lactation cows to whole sunflower seed or tallow supplementation of a diet based on barley. J. Dairy Sci. 79:1817-1825
Mikuła, R., W. Nowak, J. Jaśkowski, P. Maćkowiak, and E. Oszmałek. 2011. Effects of different starch sources on metabolic profile, production and fertility parameters in dairy cows. Pol. J. Vet. Sci. 14:55-64.

Moallem, U., H. Lehrer, M. Zachut, L. Livshitz, and S. Yacoby. 2010. Production performance and pattern of milk fat depression of high-yielding dairy cows supplemented with encapsulated conjugated linoleic acid. Animal 4:641-652.

Moate, P. J., R. Boston, I. Lean, and W. Chalupa. 2006. Short communication: Further validation of the fat sub-model in the CornellPenn-Miner Dairy model. J. Dairy Sci. 89:1052-1056.

Moate, P., W. Chalupa, T. Jenkins, and R. Boston. 2004. A model to describe ruminal metabolism and intestinal absorption of long chain fatty acids. Anim. Feed Sci. Technol. 112:79-105.

Moore, D. A., J. S. Cullor, R. Bondurant, and W. Sischo. 1991. Preliminary field evidence for the association of clinical mastitis with altered interestrus intervals in dairy cattle. Theriogenology $36: 257-265$.

Morton, J. M., M. Auldist, M. Douglas, and K. Macmillan. 2016. Associations between milk protein concentration, milk yield, and reproductive performance in dairy cows. J. Dairy Sci. 99:10033-10043.

Moussavi, A. H., M. D. Mesgaran, A. Soleimani, and T. Vafa. 2008 Effect of supplemental fish meal on reproduction and immunology responses in early lactating Holstein dairy cows. J. Anim. Vet. Adv. 7:520-525.

Neuhaus, J. M., J. D. Kalbfleisch, and W. W. Hauck. 1991. A comparison of cluster-specific and population-averaged approaches for analyzing correlated binary data. Int. Stat. Rev. 59:25-35.

Nowak, W., R. Mikuła, E. Pruszynska-Oszmalek, P. Mackowiak, B. Stefanska, M. Kasprowicz-Potocka, A. Frankiewicz, and K. Drzazga. 2013. Dietary energy density in the dry period on the metabolic status of lactating cows. Pol. J. Vet. Sci. 16:715-722.

Overton, T., and M. Waldron. 2004. Nutritional management of transition dairy cows: strategies to optimize metabolic health. J. Dairy Sci. 87:E105-E119

Petit, H. V., and H. Twagiramungu. 2006. Conception rate and reproductive function of dairy cows fed different fat sources. Theriogenology 66:1316-1324.

Plaizier, J. C., D. Krause, G. Gozho, and B. McBride. 2008. Subacute ruminal acidosis in dairy cows: The physiological causes, incidence and consequences. Vet. J. 176:21-31.

Pollott, G. E., and M. Coffey. 2008. The effect of genetic merit and production system on dairy cow fertility, measured using progesterone profiles and on-farm recording. J. Dairy Sci. 91:3649-3660.

Pryce, J. E., M. Coffey, and G. Simm. 2001. The relationship between body condition score and reproductive performance. J. Dairy Sci. 84:1508-1515.

Pryce, J., M. Royal, P. Garnsworthy, and I. L. Mao. 2004. Fertility in the high-producing dairy cow. Livest. Prod. Sci. 86:125-135.

Pryce, J., R. Veerkamp, R. Thompson, W. Hill, and G. Simm. 1997. Genetic aspects of common health disorders and measures of fertility in Holstein Friesian dairy cattle. Anim. Sci. 65:353-360.

Rabe-Hesketh, S., and A. Skrondal. 2008. Multilevel and Longitudinal Modeling Using Stata. STATA Press, College Station, TX.

Rabiee, A. R., K. Breinhild, W. Scott, H. M. Golder, E. Block, and I. J. Lean. 2012. Effect of fat additions to diets of dairy cattle on milk production and components: a meta-analysis and metaregression. J. Dairy Sci. 95:3225-3247.

Rabiee, A. R., I. J. Lean, M. A. Stevenson, and M. T. Socha. 2010. Effects of feeding organic trace minerals on milk production and reproductive performance in lactating dairy cows: A meta-analysis. J. Dairy Sci. 93:4239-4251.

Rodney, R. M., P. Celi, W. Scott, K. Breinhild, and I. Lean. 2015. Effects of dietary fat on fertility of dairy cattle: A meta-analysis and meta-regression. J. Dairy Sci. 98:5601-5620.

Rodney, R. M., J. K. Hall, C. T. Westwood, P. Celi, and I. J. Lean. 2016. Precalving and early lactation factors that predict milk casein and fertility in the transition dairy cow. J. Dairy Sci. 99:75547567 
Rogers, J. A., S. Peirce-Sandner, A. Papas, C. Polan, C. Sniffen, T. Muscato, C. Staples, and J. Clark. 1989. Production responses of dairy cows fed various amounts of rumen-protected methionine and lysine. J. Dairy Sci. 72:1800-1817.

Ruegsegger, G., and L. Schultz. 1985. Response of high producing dairy cows in early lactation to the feeding of heat-treated whole soybeans. J. Dairy Sci. 68:3272-3279.

Salfer, J. A., J. Linn, D. Otterby, W. Hansen, and D. Johnson. 1995. Early lactation responses of Holstein cows fed a rumen-inert fat prepartum, postpartum, or both. J. Dairy Sci. 78:368-377.

Senatore, E. M., W. R. Butler, and P. A. Oltenacu. 1996. Relationships between energy balance and post-partum ovarian activity and fertility in first lactation dairy cows. Anim. Sci. 62:17-23.

Siciliano-Jones, J. L., M. Socha, D. Tomlinson, and J. DeFrain. 2008. Effect of trace mineral source on lactation performance, claw integrity, and fertility of dairy cattle. J. Dairy Sci. 91:1985-1995.

Sklan, D., E. Bogin, Y. Avidar, and S. Gur-Arie. 1989. Feeding calcium soaps of fatty acids to lactating cows: effect on production, body condition and blood lipids. J. Dairy Res. 56:675-681.

Sklan, D., M. Kaim, U. Moallem, and Y. Folman. 1994. Effect of dietary calcium soaps on milk yield, body weight, reproductive hormones, and fertility in first parity and older cows. J. Dairy Sci. $77: 1652-1660$.

Skrondal, A., and S. Rabe-Hesketh. 2004. Generalized Latent Variable Modeling: Multilevel, Longitudinal, and Structural Equation Models. CRC Press, Boca Raton, FL.

Soltan, M. A. 2010. Effect of dietary chromium supplementation on productive and reproductive performance of early lactating dairy cows under heat stress. J. Anim. Physiol. Anim. Nutr. (Berl.) 94:264-272.

Son, J., R. Grant, and L. Larson. 1996. Effects of tallow and escape protein on lactational and reproductive performance of dairy cows. J. Dairy Sci. 79:822-830.

Son, J., L. Larson, and R. Grant. 2000. Effect of time of initiating dietary fat supplementation on performance and reproduction of early lactation dairy cows. Asian-Australas. J. Anim. Sci. 13:182187.

Spalding, R., R. Everett, and R. Foote. 1975. Fertility in New York artificially inseminated Holstein herds in dairy herd improvement. J. Dairy Sci. 58:718-723.
Staples, C. R., J. Burke, and W. Thatcher. 1998. Influence of supplemental fats on reproductive tissues and performance of lactating cows. J. Dairy Sci. 81:856-871.

Tedeschi, L., W. Chalupa, E. Janczewski, D. Fox, C. Sniffen, R. Munson, P. J. Kononoff, and R. Boston. 2008. Evaluation and application of the CPM dairy nutrition model. J. Agric. Sci. 146:171-182

Toni, F., L. Grigoletto, C. Rapp, M. Socha, and D. Tomlinson. 2007. Effect of replacing dietary inorganic forms of zinc, manganese, and copper with complexed sources on lactation and reproductive performance of dairy cows. Prof. Anim. Sci. 23:409-416.

can Saun, R., S. Idleman, and C. Sniffen. 1993. Effect of undegradable protein amount fed prepartum on postpartum production in first lactation Holstein cows. J. Dairy Sci. 76:236-244.

Villa-Godoy, A., T. Hughes, R. Emery, L. Chapin, and R. Fogwell. 1988. Association between energy balance and luteal function in lactating dairy cows. J. Dairy Sci. 71:1063-1072.

Wathes, D. C., M. Fenwick, Z. Cheng, N. Bourne, S. Llewellyn, D. Morris, D. Kenny, J. Murphy, and R. Fitzpatrick. 2007. Influence of negative energy balance on cyclicity and fertility in the high producing dairy cow. Theriogenology 68:S232-S241.

Westwood, C. T., I. Lean, and J. Garvin. 2002. Factors influencing fertility of Holstein dairy cows: A multivariate description. J. Dairy Sci. 85:3225-3237.

Westwood, C. T., I. Lean, J. Garvin, and P. Wynn. 2000. Effects of genetic merit and varying dietary protein degradability on lactating dairy cows. J. Dairy Sci. 83:2926-2940.

Westwood, C. T., I. J. Lean, and R. C. Kellaway. 1998. Indications and implications for testing of milk urea in dairy cattle: A quantitative review. (2) Effect of dietary protein on reproductive performance. N. Z. Vet. J. 46:123-130.

Wu, Z., and L. Satter. 2000. Milk production and reproductive performance of dairy cows fed two concentrations of phosphorus for two years. J. Dairy Sci. 83:1052-1063.

Wu, Z., L. Satter, and R. Sojo. 2000. Milk production, reproductive performance, and fecal excretion of phosphorus by dairy cows fed three amounts of phosphorus. J. Dairy Sci. 83:1028-1041.

Zebeli, Q., K. Ghareeb, E. Humer, B. Metzler-Zebeli, and U. Besenfelder. 2015. Nutrition, rumen health and inflammation in the transition period and their role on overall health and fertility in dairy cows. Res. Vet. Sci. 103:126-136. 